\title{
Transformative Tourism Breakthrough in Post Pandemic: An Enigma or Eclipse
}

\author{
Kristianus Oktriono* \\ Language Center, English Department, Faculty of Humanities, Bina Nusantara University \\ Jl. Kemanggisan Illir III No. 45, Kemanggisan, Palmerah 11480, Indonesia \\ koktriono@binus.edu
}

Received: $27^{\text {th }}$ January $2021 /$ Revised: $16^{\text {th }}$ March 2021/ Accepted: $16^{\text {th }}$ March 2021

\begin{abstract}
How to Cite: Oktriono, K. (2021). Transformative tourism breakthrough in post pandemic: An enigma or eclipse. The Winners, 22(1), 47-55. https://doi.org/10.21512/tw.v22i1.7001
\end{abstract}

\begin{abstract}
The development of tourism in Indonesia had entered a critical period, especially during the uncertain COVID-19 pandemic, which affected the tourism industry both economically and socio-culturally. Workers and stakeholders suffered as the multiplier effect of the COVID-19 outbreak. As preparation for dealing with these conditions, the tourism industry strove to adapt with a transformative business model for its sustainability. In this context, the research proposed a transformative business model for the tourism industry so that stakeholders had an adaptive and innovative frame of mind post-pandemic. The model pinpointed on personalization, closed loop, asset sharing, usage-based pricing, collaborative ecosystem, and agility as the key features. This qualitative research used case study that aimed to explore major aspects of an inspirational business model from various industries that had survived over the decades. The results describe applicable business patterns as a contribution to the tourism industry. It is suggested that tourism stakeholders focus more on developing innovative business strategies postpandemic.
\end{abstract}

Keywords: tourism industry, tourism breakthrough, COVID-19 pandemic

\section{INTRODUCTION}

Indonesia is renowned as an archipelago country. It is the largest archipelago in the world with five biggest islands, namely: Sumatra, Java, Kalimantan, Sulawesi, and Papua. With a total of 17.508 islands and 6.000 inhabited islands, Indonesia offers natural beauty and cultural richness. Moreover, its diverse cultural and natural resources become main attractions for domestic and international tourists. Indonesia is supported by biodiversity and non-living such as interesting cultures, historical sites, heritage, beaches, ecotourism, geo-parks, and nightlife. The diversity of these resources has great potential to develop in the tourism industry by involving local community. These potential elements play an important role in building the economic level. One of the strategic issues for tourism development is how to increase the tourism contribution in developing the welfare of the society, especially people at tourist destination areas (LPEM, 2018). The characteristic of tourism is the intangibility has also influenced the tourist to visit the destination (Di Matteo \& Cavuta, 2016). Hence, tourism planning is devised continuously to achieve the objectives (Martins, 2018). Furthermore, the Ministry of Tourism explains that the tourism sector contribution to the national Gross Domestic Product (GDP) has reached $9 \%$ or IDR 946,09 trillion in 2014. Consequently, tourism is considered as one of the priority sectors in national development in the Mid-Term Development Planning Period 2014-2019 (Haryana, 2020). The research highlights the problem of business survival modeling, especially in terms of the tourism context.

The research intends to propose a transformative business model for the tourism industry, so stakeholders have an adaptive and innovative solutions amidst the turbulent era. The research limits the stakeholder for tourism industry and government. The Indonesian government has set the National Medium Term Development Plan to achieve a strategic focus on tourism development. Government policies has also affected tourism policy (Andriotis, 2001). The government plans a tourism development program that implements several strategies, such as developing the tourist market, developing a tourism image, developing tourism marketing partnerships, and developing tourism promotion. The aim is to achieve the targets of tourism growth in Indonesia, which are to expand in local tourism businesses and increase the number of certified local workers. Tourism contributes 
to the multiplier effect for the community (Risman, Wibhawa, \& Fedryansyah, 2016). Table 1 presents several strategic targets in the National Medium Term Development Plan 2020-2024 in Indonesia.

In another context, the Coordinating Ministry of Economic Affairs has identified that pandemic significantly affects the tourism sector in many ways. Ministry of Law and Human Rights Indonesia presents the numbers of tourist arrival as shown in Table 2. It has decreased over the year and impacted the economic aspect. Figure 1 presents the economic impacts of the pandemic on some sectors, including tourism and hospitality industry. The health protocol has restricted the tourists' movement and led to a drop in international tourist influx. International tourist arrivals have dropped by $63 \%$ in the first quarter of 2020 ("Kunjungan wisatawan mancanegara", 2020). Besides, health issues related to the spread of the COVID-19 virus have become the major focus. This epidemic has disrupted all planning and implementation of tourism strategies, from the central to the regional levels. The impact is experienced by tourism workers, ranging from the hotel line to the aviation industry. The impact of pandemic has made the employees in tourism sectors encounter a higher risk of loss or income reduction. Tourism industry engages in downsizing through a layoff to anticipate internal condition or external factors. One of the external factors is related to the outbreak. In a bid to contain the spread of the outbreak, the government and industry need to take immediate action. Moreover, the World Travel and Tourism Council emphasizes four intertwined trends following the pandemic situation, namely demand evolution, health \& hygiene, innovation \& digitization, and sustainability (Wyman, 2020). Therefore, the research proposes

Table 1 National Medium Term Development Plan 2020-2024

\begin{tabular}{|c|c|}
\hline Strategic Objective & Target \\
\hline \multirow[t]{5}{*}{1} & Increase the number of foreign tourist visits to 20 million (2019) and 30 million (2024) \\
\hline & Increase foreign exchange in the tourism sector to 40 million USD \\
\hline & Optimize the potential of domestic tourists \\
\hline & $\begin{array}{l}\text { Creating } 10 \text { priority tourism destinations that are international in scale and fulfil the principles of } \\
\text { sustainable development, }\end{array}$ \\
\hline & International standard management organization (DMO) and Branding Wonderful Indonesia, \\
\hline \multirow[t]{4}{*}{2} & Improve the quality of infrastructure and tourism product innovation, \\
\hline & Increased Tour and Travel Competitiveness Index (TTCI) to rank 30 (2019) and 20 (2024) \\
\hline & Triple the number of MICE events and special interest tours in the next 5 years. \\
\hline & Reaching the Indonesian brand as the best destination in ASEAN to do MICE. \\
\hline 3 & $\begin{array}{l}\text { Seize a special interest in tourism opportunities. For example, ecotourism, halal tourism, underwater } \\
\text { sports, senior tourism, cruise ship tours and sailing ships. }\end{array}$ \\
\hline 4 & Human Resources Development in Tourism \\
\hline
\end{tabular}

Table 2 International Tourist Visits in 2020

\begin{tabular}{cccccccc}
\hline $\begin{array}{c}\text { Month/ } \\
\text { Region }\end{array}$ & $\begin{array}{c}\text { TOTAL } \\
\text { ASEAN }\end{array}$ & $\begin{array}{c}\text { TOTAL } \\
\text { ASIA (Excl. } \\
\text { ASEAN) }\end{array}$ & $\begin{array}{c}\text { TOTAL } \\
\text { EUROPE }\end{array}$ & $\begin{array}{c}\text { TOTAL } \\
\text { AMERICA }\end{array}$ & $\begin{array}{c}\text { TOTAL } \\
\text { OCEANIA }\end{array}$ & $\begin{array}{c}\text { TOTAL } \\
\text { AFRICA }\end{array}$ & $\begin{array}{c}\text { GRAND } \\
\text { TOTAL }\end{array}$ \\
\hline January & 440.561 & 457.409 & 156.435 & 49.183 & 133.728 & 7.087 & 1.272 .083 \\
February & 327.468 & 222.035 & 153.551 & 42.947 & 99.243 & 5.142 & 863.960 \\
March & 192.199 & 128.608 & 77.687 & 19.847 & 45.932 & 2.877 & 470.970 \\
April & 68.000 & 86.308 & 1.806 & 1.229 & 1.174 & 46 & 158.718 \\
May & 73.900 & 84.719 & 2.238 & 1.155 & 1.423 & 51 & 163.646 \\
June & 68.490 & 84.645 & 2.250 & 1.209 & 1.429 & 62 & 158.256 \\
July & 63.760 & 88.557 & 2.310 & 1.499 & 1.519 & 79 & 157.939 \\
August & 63.484 & 93.526 & 2.777 & 1.901 & 1.190 & 53 & 163.185 \\
September & 60.503 & 85.682 & 4.142 & 1.686 & 1.067 & 80 & 153.498 \\
October & 54.548 & 92.249 & 6.057 & 3.409 & 1.436 & 130 & 158.189 \\
November & - & - & - & - & - & - & - \\
December & - & - & - & - & - & - \\
\hline
\end{tabular}


a transformative business model for the tourism industry in general. It is expected to be a contribution for tourism industry practitioners to foresee tourism conditions holistically after the pandemic.

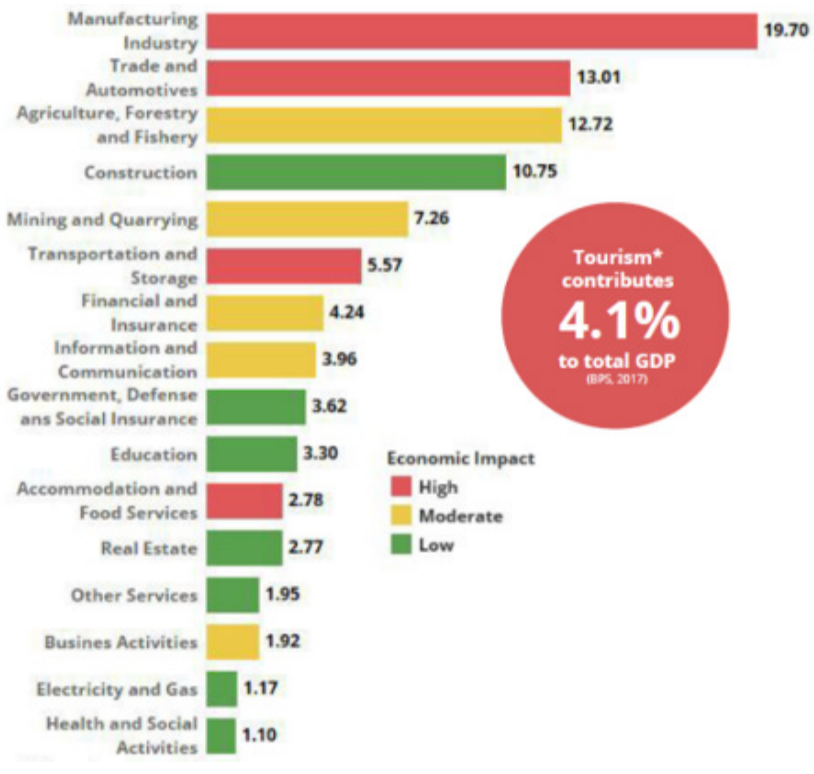

Figure 1 Macroeconomic Impacts on Sectors

World Tourism Organization (UNWTO) defines tourism as a social, cultural, and economic phenomenon which entails the movement of people to countries or places outside their usual environment for personal or business/professional purposes. Tourism is supported by some elements that amplified tourism sustainability, especially at a destination. Tourism consists of three elements including attraction, accessibility, and amenities (Leiper, 1990; Hall \& Page, 2010). These components have become important factors to attract all tourists to destinations (Ismail \& Fatchur, 2019). The pull factors of 3As attract the tourists' attention. Tourism in certain areas requires a proper tourism component to be developed to meet the tourists' need (Andrianto \& Sugiama, 2016). UNWTO emphasizes sustainable tourism that takes full account of current and future economic, social and environmental impacts, meeting the needs of visitors, industry, environment, and local communities (Danu \& Urmila, 2019). Tourism, as an amalgamation of the business system, includes varies tourism services and covers a wide range of service and hospitality sectors. From the tourism chain perspective, technology can take part in services produced by the network with partners and competitors from various advantages (Reinhold et al., 2019). The balanced consideration of sustainability dimensions involved the economy, environment and society. They form the basis of successful long-term development of a tourism destination (Weber, 2019).

Firstly, the attraction is the most important element that motivates people to travel, which includes natural attraction and man-made attraction. It triggers tourists to the preconditions of travel and provides a sense of pleasure. In other words, tourism attracts the tourists to enjoy the experience and involves them in series of tourism activities.

The aspect of accessibility is an essential key element for tourism development as it mediates tourists to reach the selected destination. The mode of transportation is provided to minimize travelling time, which is grouped into the land, air, and water transportation. At the same time, the optimization of time spent at the destination becomes extra value for tourist.

Lastly, the amenities and accommodation include extra facilities, cuisine, lodging facilities for the guest. These parts contribute not only to the aspect of comfortability for the guest, but also complementary to the attraction. In this sense, tourism offers an eclectic mix of memorable and ecstatic experience.

In terms of macroeconomic aspects, five sectors are affected by the outbreak, namely: 1) manufacturing, 2) wholesale and retail trade, 3) repairs of motor vehicles and motorcycles, 4) transportation and storage, and 5) accommodation and services (World Food Programme, 2020). Tourism-related activities fall under multiple sectors, which include: 1) other accommodation, food, and beverages, 2) transportation and storage, 3) real estate, and 4) company services. Figure 2 exhibits the high impact of pandemic towards tourism labour market from the perspective of macroeconomic.

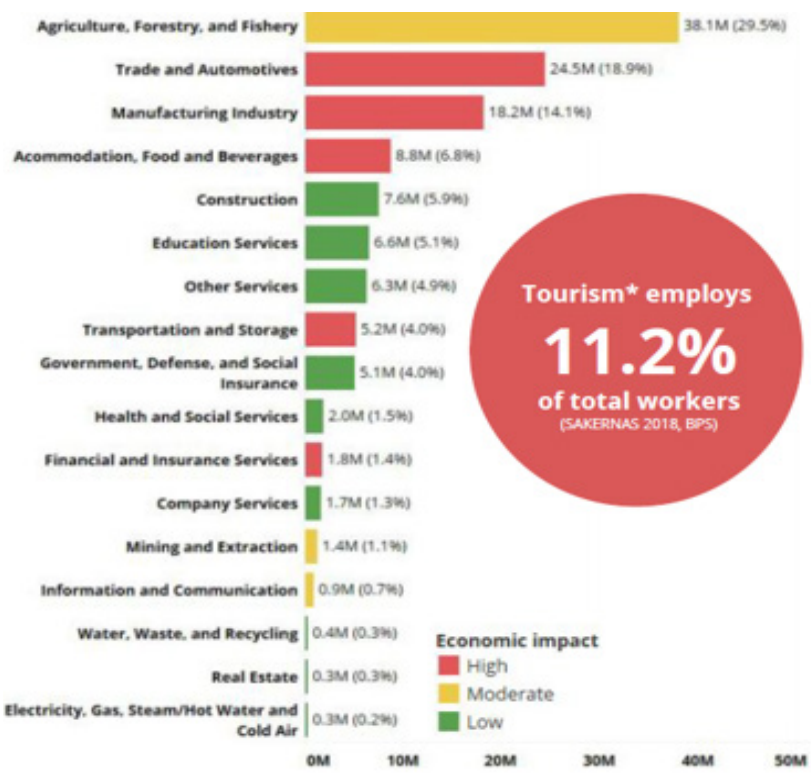

Figure 2 Macroeconomic Impacts on Employment (World Food Programme, 2020)

Responding to its sustainability and pandemic condition, the tourism industry should focus to invent innovative ways to survive. The industry should keep up with the changing market condition that correlates with value and experience by the business model. Casadesus-Masanell and Ricart (2010) define a business model as a reflection of the organization's 
strategy. The organization should construct the business model as the foundation before it deploys the strategy. Casadesus-Masanell and Ricart (2010) pinpoint that each business has a unique model to achieve its outcomes. The interactions among business models are directed to value creation for tourist. They also highlight the choices and consequences in the business model, where choices consider the policies, assets, and governance.

In this context, Mkhize \& Ivanovic (2020) underline that the prevalence of creative culture, specifically in tourism, is a necessity to create new and original experiences. Technically, it redefines the transformative journey that embodies the tourist's consumption and learning. Meanwhile, the consequences should consider the aspect of flexible and rigid. Arguably, the organization continues to strengthen the competitive advantages in the market. Furthermore, Johnson, Christensen, and Kagermann (2008) explicate that a business model should consist of four elements, namely: 1) customer value proposition, 2) profit formula, 3) key resources, and 4) key processes. In addition, Casadesus-Masanell and Ricart (2010) highlight that a good business model should meet three criteria, which are: 1) the alignment with organization goals, 2) self-reinforcement, and 3) sustainability. Therefore, stakeholders in tourism need to develop a digital-based business model to improve Indonesia's tourism activities since the business constellation of the $21^{\text {st }}$ century has changed drastically. In the digital age, business competition is no longer only about products or services, but also business model competition.

\section{METHODS}

This is a qualitative research which, in epidemic, has made major changes in thinking, involving the subjective role of social scientists (Wilson et al., 2020). The research uses a case study as a method. The theoretical basis emphasizes the agile guideline so that it directs the processes and meanings in this informative phenomenon. Qualitative research has several characteristics such as being descriptiveanalytical (collecting and compiling data that provide in-depth explanations). Tourism research, as emphasized by Pritchard, Morgan, and Ateljevic (2011), is characterized by extraordinary growth and increased fragmentation. In addition, the nature of the research is inductive, which is initiated from the data or phenomena in the field which lays the foundation for the theory. As a strategy, the qualitative investigation can induce theory based on research, emphasize understanding from the perspective of its participants, and view social life as a result of interaction and interpretations (Goodson \& Phillimore, 2004).

Data is retrieved from many sources, namely: 1) Central Bureau Statistics Indonesia (Badan Pusat Statistik), 2) Ministry of Law and Human Rights, 3) Ministry of National Development Planning, 4) World
Tourism Organization (UNWTO), 5) World Travel \& Tourism Council (WTTC), 6) Ministry of Tourism, 7) World Food Programme (WFP), 8) Harvard Business Review, 9) Ministry of Finance in Indonesia, and 10) relevant journals. The secondary data reference ranges from 2000 to 2020. Data analysis is described analytically based on the case study model selected.

The research proposes a transformative business model by Kavadias, Ladas, and Loch (2016) to address the changing and demand linkage as presented in Figure 3. The model describes the link between technology and the market. In this model, six elements characterize the successful innovation that relates both components.

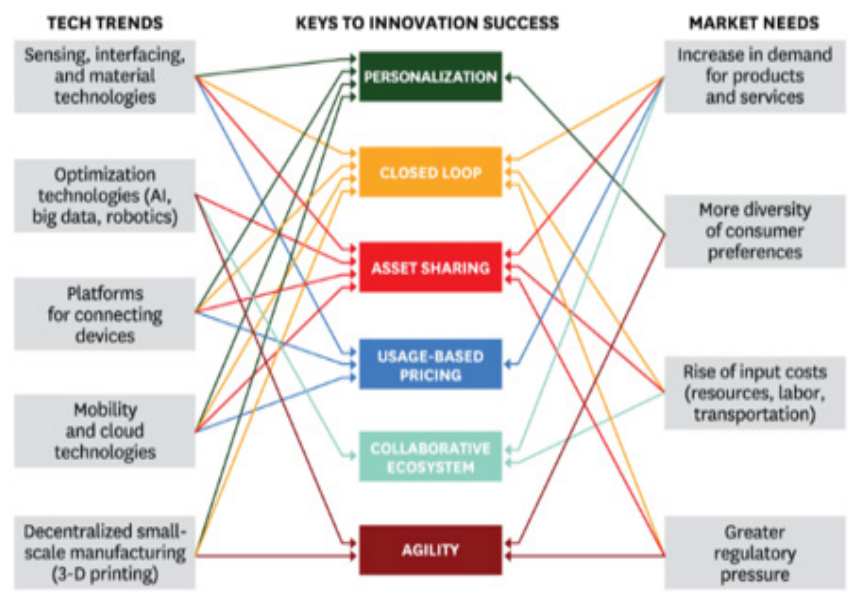

Figure 3 Transformative Business Model

Tourism system is represented by Leiper's diagrammatic model in Figure 4 (Hall \& Page, 2010). Indonesia is supported by $3 \mathrm{As}$ as the destination region. Technically, these aspects are also influenced by environmental elements such as physical, technological, social, cultural, economic, and political. In the perspective of tourism planning, it can be categorized into three levels, namely national, regional, and site levels (Wijaya et al., 2020). As the pull factors, destinations received support from all stakeholders to infuse competitiveness advantage in tourism. Therefore, management of tourism destinations is required since the number of tourists will increase so that the level of satisfaction becomes important (Khuong \& Ha, 2014). Specifically, it influences the tourist experience as memorable indicators (Subadra et al., 2019). Moreover, the tourism sector deals with high level of competition, so marketers must find the most effective way to maintain the level of competition, and increase the prestige of tourism destinations (Katsikari et al., 2020).

Based on implementation outlook of global tourism in the next few years, it will be influenced by ten Tourism Megatrends from two sides, demand and supply (Tutek et al., 2015) as shown in Figure 5. Regarding the demand, the trend is divided into five, namely: 1) silver hair tourist, 2) generation $\mathrm{X} \& \mathrm{Y}$, 
3) growing middle class, 4) emerging destinations, and 5) political issues and terrorism. While from the supply, the trend is divided into five which are: 1) technological revolution, 2) digital channels, 3) loyalty v.X.0, 4) health and healthy lifestyle, and 5) sustainability.

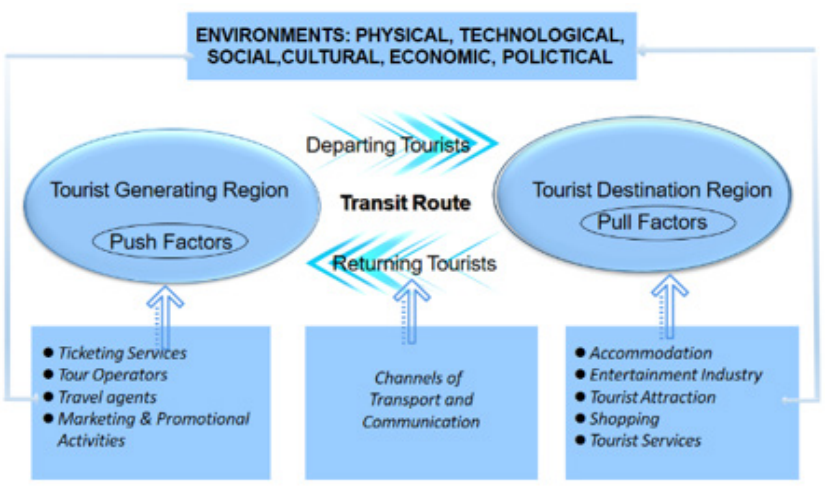

Figure 4 Basic Tourism System

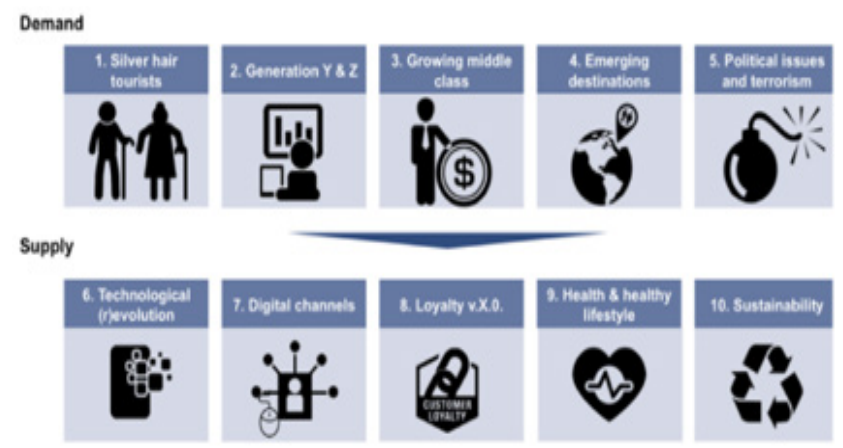

Figure 5 Tourism Megatrends

The population of senior citizens (aged over 60 years) in the world will increase, which predicts the $21 \%$ share of total international tourists (Tutek et al., 2015). It encourages the emergence of a new tourism segment for the elderly. Moreover, the segment of Generation $\mathrm{Y}$ is growing rapidly. It is expected to represent $50 \%$ of tourists in 2025 . The focus of millennials on travelling is exploration, interaction, and emotional experiences. The middle class increased from 1,8 billion in 2009 to 3,2 billion in 2020. It is expected to increase to 4,9 billion in 2030 . The increase in the middle class will change the tourists' profile. The majority of the middle class derives from the Asia Pacific region which represents two-thirds of the global middle-class population and contributes to $59 \%$ of middle-class consumption by 2030. The growth and the characteristics of the middle class in selecting tourism destinations will encourage the expansion of many tourism destinations in developing countries such as Indonesia. However, terrorism issues or tragic events can lead to major setbacks and decrease in the number of international visitors.

The internet has changed the way travellers search and browse information, book and travel. The use of robots, interactive displays and smartphones will become an inseparable part of the tourism sector. As this backdrop, internet penetration encourages the start and end of holiday activities with the internet. Now, tourists provide feedback after a vacation about their experiences through social media. In $2013,65 \%$ of searching started from using a cell phone to a computer. Furthermore, loyalty programs are integrated with travel experiences by combining speed in responding to dynamic digital environments. Tourists are increasingly concerned about a healthy lifestyle and a key factor in improving health. Due to higher awareness of health and rapid development of technology, the emergence of tourism businesses such as spa parlors are encouraged. Sustainable tourism respects the local population and other tourists, cultural heritage and the environment. Arguably, sustainable tourism development should balance three pillars, namely the social pillar, the environmental pillar and the economic pillar.

\section{RESULTS AND DISCUSSIONS}

Tourism has the potential to become a contributor to foreign exchange, GDP and labour in Indonesia. In 2017, the tourism sector contributed $5 \%$ to the National GDP, with a total foreign exchange of 200 trillion rupiahs and employed 12,28 million workers in the tourism sector. It has 15 million international tourist visits and 265 million trips by domestic tourists. This indirectly promotes the 'Wonderful Indonesia' branding which had received 103 awards from 2016 to 2018. In the investment sector, the trend of private sector investment continues to increase from 2013 to 2017 with the realization of USD 1,788 million. To streamline the investment program, tourism needs support in terms of government regulations. A common problem in Indonesia is overlapping regulations, in which the government continues to perform deregulation efforts, including the tourism sector to increase growth. One example is the deregulation of visiting visas for 90 countries in 2015 changing to 169 countries in 2016 through Presidential Regulation Number 21 of 2016 concerning free Visa on Arrival. Based on Immigration data for January - August 2017, there are 49 visa-free countries whose tourist visits are less than 150 so they need a review.

Human resources in tourism is one of the important pillars in the implementation of national tourism. Based on Government Regulation Number 50 of 2017 (National Tourism Development Master Plan 2010-2025), the development of tourism human resources is one of the mandates that must be realized immediately. The Ministry of Tourism has assisted in the implementation of expert certification in the tourism sector. It continues to escalate in certification for the tourism sector workforce of 65.000 with an increase of $85 \%$ in 2017. At this point, the government should pay attention to the implementation of labour certification in the tourism sector, such as the adequate 
number of Professional Certification Bodies. The government should pay attention to equal distribution throughout Indonesia and the sufficient number of assessors for the implementation of competency tests.

In accordance with the vision of the Ministry of Tourism and Creative Economy in 2020, the government has the initiative to create advanced, competitive, and sustainable tourism and creative economy in Indonesia that prioritizes local wisdom in realizing an Indonesia excellence known as sovereign and independent with a personality based on cooperation (Kemenparekraf/Baparekraf, 2020). Ministry of Tourism and Creative Economy for 20202024 aims to improve the contribution of tourism and creative economy to national economic resilience. The achievement of this goal is measured through three indicators, namely: 1) tourism foreign exchange value, 2) tourism GDP contribution, and 3) creative economy product export value.

Analysis of tourism problems is conducted by following the pillars of tourism development. Based on Law Number 10 of 2009 concerning tourism, tourism development in Indonesia includes four central points, which are: 1) tourism destinations, 2) marketing, 3) the tourism industry, and 4) tourism institutions. Firstly, the main challenges in developing tourism destinations include: 1) climate change and natural disasters, 2) availability of connectivity, 3 ) inadequate infrastructure, 4) minimum community readiness around tourism destinations, and 5) insufficient ease of investment. In addition, the challenges in developing tourism marketing comprise the absence of a comprehensive market reference, unintegrated marketing communication strategy, unoptimized marketing partnership synergy, partial promotional activities, and the insignificant positive image.

Subsequently, the main challenges in the development of the tourism industry include the inadequate synergy of the tourism business chain, weak competitiveness of tourism products, the gap between the price level and tourism experience, insufficient tourism business partnerships, and insignificant development of environmental responsibility by tourism businesses. Lastly, the main problems related to the development of tourism institutions encompass unequal strengthening of tourism organizations in the regions, limited tourism human resources and tourism higher education development, and ineffective coordination and synchronization of development across regions and sectors.

The contemporary national tourism development directs towards the Quality Tourism Experience. In line with this guide, UNWTO in Practical Guidelines for Integrated Quality Management in Tourism Destination states that the quality of a tourism destination is the result of a process which implies the satisfaction of all tourism product and service needs, customers' requirements and expectations, mutually accepted contractual conditions and the underlying implicit factors. UNWTO also emphasizes that quality represents three elements, namely professionals tools, management models, and powerful marketing tools.

Reflecting on the fundamental challenges, internal conditions, and external factors, the research proposes a transformative business model by Kavadias et al. (2016). They selected and analyzed 40 new business models that have the potential to transform their industries with correlated features and success opportunity (Kavadias et al., 2016). As a result, they pinpoint six key features of innovation success, namely: 1) more personalized products or services, 2) a closed-loop process, 3) asset sharing, 4) usage-based pricing, 5) more collaborative ecosystem, and 6) an agile and adaptive organization.

Offers for personalized products or services should be improved, which means they are customized representing customers' personal and fundamental necessity. The tourism industry should leverage technology to reach the customers' heart with affordable pricing.

The next feature is a closed-loop process that minimizes overall resource expenses. In the tourism industry, expenses are related to reducing the potential cost at all levels of business, starting upstream to downstream lines. The characteristics of tourism, such as intangible, inseparable, and volatile have become the consideration in creating a product with minimum risk. The cost related to the supply chain should be managed from the perspective of demand and supply as effective as possible.

Next, regarding resource sharing, stakeholders optimized the utilization of sharing assets. The stakeholders does not only receive the benefit from the business, but also share the economic value to minimize entry barriers in industries. In this context, private housing minimizes the spread of the outbreak. In the end, tourism counterpart will contribute evenly to the user and provider.

The subsequent feature focuses on the price. The customer will receive more intrinsic values beyond the extrinsic economic value. This feature is to provide an outstanding experience and a memorable journey that leads to satisfaction and loyalty. Eventually, all stakeholders in the tourism industry strive to innovate the ideas for heterogeneous services.

The other prominent feature is the collaborative ecosystem. In this frame, tourism should involve and empower all related stakeholders. The collaboration should make use of technology by innovating its utilization and reducing the risk.

The last feature concerns a swift and adaptive organization. The tourism industry is trying to optimize the role of technology in making decisions quickly and accurately using an adaptive decisionmaking model that is more adaptive to market needs. It is certainly related to the value proposition for the user. The goal is to increase satisfaction not solely on the part of the user, but also from the service provider since it is associated with the allocation of costs and scarce resources.

The next analysis is mapping of the six keys to successful innovation by involving technological 


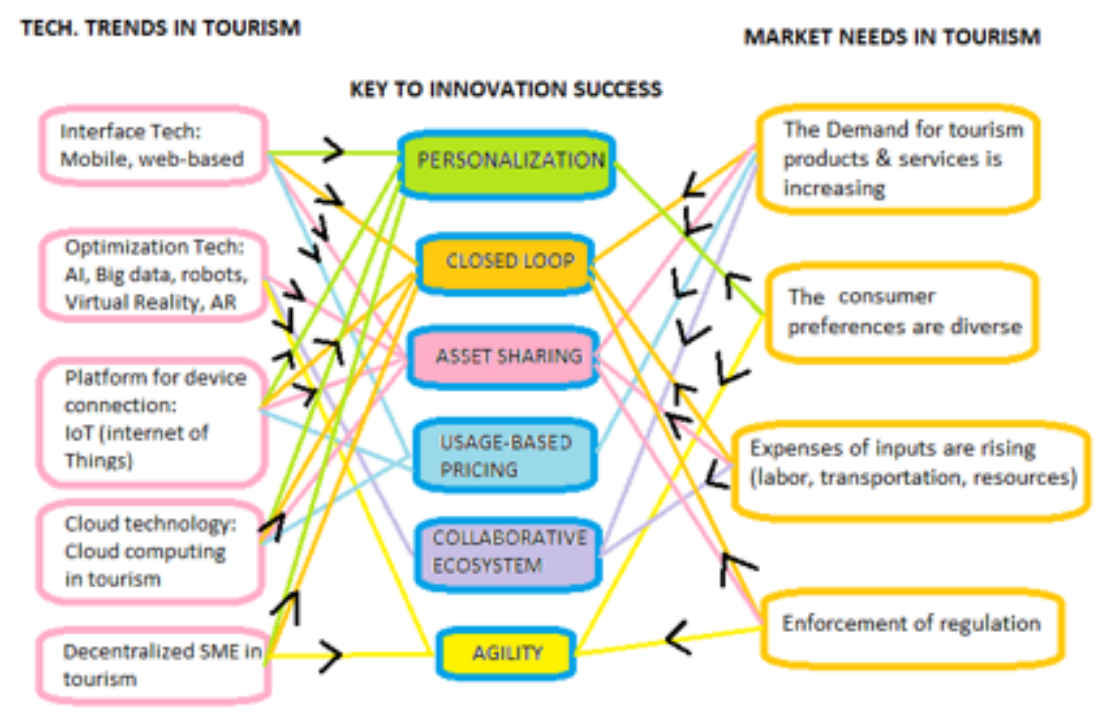

Figure 6 Proposed Transformative Business Model

trends and market needs in the context of Indonesian tourism as shown in Figure 6.

In terms of technology trends, tourism stakeholders in Indonesia should map technologysupporting and infrastructure components such as internal conditions in each region in an integrated database. The function is to classify the advantages of Indonesian tourism. This advantage is divided into two clusters, namely the customer portfolio and product portfolio. In the customer portfolio, Indonesian tourism focuses on the personal, business and international segments. Meanwhile, the product portfolio focuses on nature, culture, and man-made.

In the interface of technology, tourism service providers focus more on delivering web and smartphone-based products and services. To support this, providers should optimize the use of Artificial Intelligence (AI), big data, and virtual reality to facilitate data access in every transaction. To maintain security, transactions are equipped with blockchain technology. Presumably, the internet of things platform is an important concern since it simplifies exchanging data and information and connecting with authorized software for all counterparts. In particular, the decentralization of Small Medium Enterprise (SME) in tourism is also an important pillar in the development of sustainable tourism. In terms of market needs in tourism, demand for products and services continues to increase annually. This is supported by the uniqueness of tourist destinations and the strength of their branding. This request is accommodated by service providers by paying attention to optimal costreduction, the use of asset sharing, and determining prices according to customized conditions. With this in mind, the value proposition is continuously maintained and increased with a digital-based collaboration system. From the provider's perspective, market needs must be facilitated due to the changing behavior of tourists. The cost factor also considers the good congruence between the assets used, the costs incurred by all parties and the satisfaction received by the user. From a regulatory perspective, the government needs to establish strict rules and protect the safety and comfort of guests and business owners eventually.

\section{CONCLUSIONS}

The analysis of tourism challenges should address the pillars of tourism development. In Law Number 10 of 2009 about tourism, tourism development in Indonesia involves four major points, which are tourism destinations, marketing, the tourism industry, and tourism institutions. Tourism needs to transform from a destination perspective into the vital sustainable concept as the industry must adapt to the turbulence change. It needs providers' capability to attract market interest.

A transformative business model should represent the level of adaptability to all changes, both in terms of demand, supply, and technology. Technically, six features are the main indicators of a transformative business model classified into a more personalized product or service, a closed-loop process, asset sharing, usage-based pricing, a more collaborative ecosystem, and an agile and adaptive organization. The research suggests tourism transformation as an industry. A transformative business model must display at least three out of the six key features of the transformative business model. The research proposes that these six features are integrated synchronously by government, industry, and community-based tourism. It is suggested that further research explore deeply in terms of the role of community-based tourism in realizing the vision and mission of sustainable tourism. 


\section{REFERENCES}

Andrianto, T. \& Sugiama, G. (2016). The analysis of potential 4A's tourism component in the Selasari rural tourism, Pangandaran, West Java. $12^{\text {th }}$ Biennial Conference of Hospitality and Tourism Industry in Asia, 138-144. https://doi.org/10.2991/atf16.2016.21.

Andriotis, K. (2001). Tourism planning and development in Crete: Recent tourism policies and their efficacy. Journal of Sustainable Tourism, 9(4), 298-316. https://doi.org/10.1080/09669580108667404.

Casadesus-Masanell, R. \& Ricart, J. E. (2010). From strategy to business models and onto tactics. Long Range Planning, 43(2-3), 195-215. https://doi. org/10.1016/j.lrp.2010.01.004.

Danu, P. I. K. S. \& Urmila, D. M. H. (2019). The effect of number of tourists and general bank credits on hotel room offers, women workers and growth of tourism sector in the province of Bali. Russian Journal of Agricultural and Socio-Economic Sciences, 94(10), 209-219. https://doi.org/10.18551/rjoas.2019-10.28.

Di Matteo, D. \& Cavuta, G. (2016). Enogastronomic tourism: Can it mitigate the intangibility of the destination? Streetfood as a new business model for the management of tourist regions. Procedia Economics and Finance, 39, 347-356. https://doi. org/10.1016/s2212-5671(16)30335-5.

Goodson, L. \& Phillimore, J. (2004). Qualitative Research in Tourism: Ontologies, Epistemologies and Methodologies ( $1^{\text {st }}$ Ed.). London: Routledge. https:// doi.org/10.4324/9780203642986.

Hall, C. M. \& Page, S. (2010). The contribution of Neil Leiper to tourism studies. Current Issues in Tourism, 13(4), 299-309. https://doi.org/10.1080/13683500.2 010.482652 .

Haryana, A. (2020). Economic and welfare impacts of Indonesia's tourism sector. Jurnal Perencanaan Pembangunan: The Indonesian Journal of Development Planning, 4(3), 300-311. https://doi. org/10.36574/jpp.v4i3.127.

Ismail, T. \& Fatchur, R. (2019). The role of attraction, accessibility, amenities, and ancillary on visitor satisfaction and visitor attitudinal loyalty of Gili Ketapang beach. Jurnal Manajemen Teori Dan Terapan, 2, 149-165. http://library1.nida.ac.th/ termpaper6/sd/2554/19755.pdf.

Johnson, M. W., Christensen, C. M., \& Kagermann, H. (December 2008). Reinventing your business model. Harvard Business Review, https://hbr.org/2008/12/ reinventing-your-business-model.

Katsikari, C., Hatzithomas, L., Fotiadis, T., \& Folinas, D. (2020). Push and pull travel motivation: Segmentation of the Greek market for social media marketing in tourism. Sustainability, 12(11), 1-18. https://doi.org/10.3390/su12114770.

Kavadias, S., Ladas, K., \& Loch, C. (October 2016). The transformative business model. Harvard Business Review. https://hbr.org/2016/10/the-transformativebusiness-model?utm_source $=$ Cambridge $\% 20$ Judge \% 20 Busines s $\% 20 \mathrm{School} \&$ ut m medium=email\&utm_campaign $=7519407$ Media\%20summary\% $\%$ 209\%20September $\% 2 \overline{0}$ 2016\&dm_i=HVY,4H60F,EFFS53,GIYKC,1.

Kementrian Pariwisata dan Ekonomi Kreatif. (2020). Rencana Strategis 2020-2024. https://www. kemenparekraf.go.id/asset_admin/assets/uploads/ media/pdf/media_1598 887965 Rencana strategis 2020-2024.pdf.

Khuong, M. N. \& Ha, H. T. T. (2014). The influences of push and pull factors on the International leisure tourists' return intention to Ho Chi Minh City, Vietnam A mediation analysis of destination satisfaction. International Journal of Trade, Economics and Finance, 5(6), 490-496. https://doi.org/10.7763/ ijtef.2014.v5.421.

Kunjungan wisatawan mancanegara per bulan menurut kebangsaan (kunjungan). (2020). Badan Pusat Statistik. https://www.bps.go.id/indicator/16/1470/2/ kunjungan-wisatawan-mancanegara-per-bulanmenurut-kebangsaan.html.

Leiper, N. (1990). Tourist attraction systems. Annals of Tourism Research, 17(3), 367-384. https://doi. org/10.1016/0160-7383(90)90004-B.

Lembaga Penyelidikan Ekonomi dan Masyarakat (LPEM) Fakultas Ekonomi dan Bisnis, Universitas Indonesia. (2018). Laporan Akhir: Kajian Dampak Sektor Pariwisata terhadap Perekonomian Indonesia. https://www.kemenparekraf.go.id/asset_admin/ assets/uploads/media/pdf/media_15544337393 Laporan_Akhir.pdf.

Martins, M. (2018). Tourism planning and tourismphobia: An analysis of the strategic tourism plan of Barcelona 2010-2015. Journal of Tourism, Heritage \& Services Marketing, 4(1), 3-7. https://mpra.ub.uni-muenchen. de $/ 88203 /$.

Mkhize, S. L. \& Ivanovic, M. (2020). Building the case for transformative tourism in South Africa. African Journal of Hospitality, Tourism and Leisure, 9(4), 717-731. https://doi.org/10.46222/ ajhtl.19770720-47.

Pritchard, A., Morgan, N., \& Ateljevic, I. (2011). Hopeful tourism: A new transformative perspective. Annals of Tourism Research, 38(3), 941-963. https://doi. org/10.1016/j.annals.2011.01.004.

Reinhold, S., Zach, F. J., \& Krizaj, D. (2019). Business models in tourism - state of the art. Tourism Review, 74(6), 1120-1134. https://doi.org/10.1108/TR-022018-0027.

Risman, A., Wibhawa, B., \& Fedryansyah, M. (2016). Kontribusi pariwisata terhadap peningkatan kesejahteraan masyarakat Indonesia. Prosiding Penelitian dan Pengabdian kepada Masyarakat, 3(1). https://doi.org/10.24198/jppm.v3i1.13622.

Subadra, I. N., Sutapa, I. K., Artana, I. W. A., Yuni, L. K. H. K., \& Sudiarta, M. (2019). Investigating push and pull factors of tourists visiting Bali as a world tourism destination. International Journal of Multidisciplinary Educational Research, 8(7), 253269. https://ijmer.s3-ap-southeast-1.amazonaws. com/pdf/volume8/volume8-issue8(7)-2019/22.pdf.

Tutek, E., Gebbie, M., Chan, K. Y., \& Durand, S. (2015). 
Tourism megatrends: 10 things you need to know about the future of tourism. Howarth HTL, 15. www. hospitalitynet.org/news/4073042.html.

Weber, F. (2019). Demand for sustainable tourism. In D. Lund-Durlacher, V. Dinica, D. Reiser, M. S. Fifka (Eds.), Corporate Sustainability and Responsibility in Tourism: A Transformative Concept. Springer. https://www.springer.com/gp/book/9783030156237.

World Food Programme. (2020). COVID-19: Economic and Food Security Implications. https://docs.wfp. org/api/documents/WFP-0000116063/download/.

Wijaya, P. Y., Kawiana, I. G. P., Suasih, N. N. R., Hartati, P. S., \& Sumadi, N. K. (2020). Swot and Micmac analysis to determine the development strategy and sustainability of the Bongkasa Pertiwi tourism village, Bali province, Indonesia. Decision Science Letters, 9(3), 439-452. https://doi.org/10.5267/j. ds1.2020.3.002.

Wilson, E., Mura, P., Sharif, S. P., \& Wijesinghe, S. N. R. (2020). Beyond the third moment? Mapping the state of qualitative tourism research. Current Issues in Tourism, 23(7), 795-810. https://doi.org/10.1080/ 13683500.2019 .1568971$.

Wyman, O. (2020, September 27). WTTC launches new report on the future of travel \& tourism in a postCOVID world. World Travel \& Tourism Council. https://wttc.org/News-Article/WTTC-LaunchesNew-Report-on-the-Future-of-Travel-and-Tourismin-a-Post-COVID-World. 